Article

\title{
IMPACT OF TRELLIS SYSTEMS AND ROOTSTOCKS ON GLOBAL PHENOLIC COMPOSITION AND ANTIOXIDANT ACTIVITY OF 'ISABEL PRECOCE' GRAPES PRODUCED DURING RAINY SEASONS IN SEMI-ARID REGION OF BRAZIL
}

\section{IMPACTO DE SISTEMAS DE CONDUÇÃO E PORTA-ENXERTOS NA COMPOSIÇÃO FENÓLICA GLOBAL E NA ATIVIDADE ANTIOXIDANTE DE UVAS 'ISABEL PRECOCE' PRODUZIDAS DURANTE OS PERÍODOS CHUVOSOS NA REGIÃO SEMIÁRIDA DO BRASIL}

\author{
Rayssa R. da Costa ${ }^{1}$, Talita de O. Ferreira ${ }^{2}$, Débora T. Felix ${ }^{3}$, Maria A.C. de Lima ${ }^{4, *}$ \\ ${ }^{1}$ Departamento de Agronomia, Universidade Federal da Paraíba/CCA, Rodovia PB-079, CEP 58397-000, Areia/Paraíba, Brazil. \\ ${ }^{2}$ Departamento de Produção Vegetal, Universidade Federal do Vale do São Francisco, Rodovia BR 407, Lote 543, Projeto de Irrigação Nilo \\ Coelho, CEP 56300-990, Petrolina/Pernambuco, Brazil. \\ ${ }^{3}$ Programa de Pós-Graduação em Ciência e Tecnologia de Alimentos, Universidade Federal de Sergipe, Av. Marechal Rondon, s/n, Jardim \\ Rosa Elze, CEP 49100-000, São Cristóvão/Sergipe, Brazil. \\ ${ }^{4}$ Embrapa Semiárido, Rodovia BR-428, Km 152, Zona Rural, Caixa Postal 23, CEP 56302-970, Petrolina/Pernambuco, Brazil. \\ * Corresponding author: Tel.: + 5587 3866-3831; e-mail: auxiliadora.lima@embrapa.br.
}

(Received 22.03.2021. Accepted 26.07.2021)

SUMMARY

Crop components, such as trellis systems, might affect solar radiation uptake by grapevines while others, such as rootstocks, influence the vigor of the scion. Proper management provides a suitable reproductive and vegetative balance that could influence the chemical composition of grapes. This study aimed to characterize the global phenolic composition and antioxidant activity of 'Isabel Precoce' grapes raised for juice, growing under different trellis systems and rootstocks, in rainy seasons, in semi-Arid conditions in Brazil. With a randomized block experimental design and split-split plots over time, the overhead trellis, lyre, and vertical shoot positioning systems and two rootstocks ('IAC 572' and 'IAC 766') in the harvest seasons of January-May, 2017 and January-May, 2018 were studied. Trellis systems, rootstocks, harvest seasons and their interactions affected the characteristics of the grapes. The treatments with equivalent responses in the seasons defined the specific characteristics of the grapes. The rootstock 'IAC 766' provided greater bunch weight and lower acidity to the 'Isabel Precoce' grapes, while 'IAC 572' induced higher soluble solids contents. In both seasons, there was lower variation in berry resistance to compression and polyphenol and anthocyanin contents in grapes from grapevines grown on an overhead trellis. In turn, the use of lyre provided high antioxidant activity by the $\mathrm{ABTS}^{\bullet+}$ method in 2018. The highest antioxidant activity by the $\mathrm{DPPH}^{\bullet}$ method was due to the association of overhead trellis and 'IAC 766'. With the use of the overhead trellis, equivalent phenolic compounds and antioxidant activity during the seasons resulted in a uniform quality.

\section{RESUMO}

Componentes da cultura da vinha, como sistema de condução, podem afetar a captação da radiação solar na videira enquanto outros, como porta-enxertos, influenciam o vigor da copa. Com uma condução adequada, é possivel obter um balanço reprodutivo e vegetativo equilibrado que pode influenciar a composição química das uvas. Este estudo teve como objetivo caracterizar a composição fenólica global e a atividade antioxidante da uva para suco 'Isabel Precoce' cultivada em diferentes sistemas de condução e porta-enxertos, em safras do período chuvoso, nas condições do Semiárido Brasileiro. Em delineamento experimental em blocos ao acaso, em parcelas subsubdivididas no tempo, foram estudados os sistemas de condução latada, lira e espaldeira e dois porta-enxertos ('IAC 572' e 'IAC 766'), nas safras de janeiro-maio de 2017 e janeiro-maio de 2018. Sistemas de condução, porta-enxertos, safras ou interações entre eles afetaram as características das uvas. Os tratamentos com respostas equivalentes nas safras definiram características específicas da uva. O porta-enxerto 'IAC 766' proporcionou maior peso dos cachos e menor acidez às uvas 'Isabel Precoce' enquanto 'IAC 572' induziu maiores teores de sólidos solúveis. Entre safras, observou-se menor variação na resistência à força de compressão, teores de polifenóis e de antocianinas nas uvas de videiras em latada. Por sua vez, o uso da lira proporcionou elevada atividade antioxidante pelo método ABTS ${ }^{\bullet+}$, em 2018 . A maior atividade antioxidante pelo método $\mathrm{DPPH}^{\bullet}$ foi decorrente da associação latada-'IAC 766'. Em latada, compostos fenólicos e atividade antioxidante equivalentes entre safras determinaram qualidade uniforme.

Keywords: antioxidant activity, phenolic compounds, rootstocks, trellis systems, tropical vitiviniculture.

Palavras-chave: atividade antioxidante, compostos fenólicos, porta-enxertos, sistemas de condução, vitivinicultura tropical.

126

(C) Costa et al., 2021.

This is an Open Access article distributed under the terms of the Creative Commons Attribution License

(https://creativecommons.org/licenses/by/4.0), which permits unrestricted use, distribution, and reproduction in any medium, provided the original work is properly cited. 


\section{INTRODUCTION}

Traditionally, vineyard areas around the world have been in regions with temperate climates. However, a large number of grapevine cultivars have adapted to other climatic conditions, especially hot and dry climates, which has thus enabled the development of tropical viticulture (Soares and Leão, 2009). Viticultural activity was established in the Brazilian semi-arid region over 40 years ago, with the cultivation of table grapes and grapes intended for winemaking. With the use of irrigation, two harvest seasons are obtained each year under tropical conditions. However, alternating production is common between successive cycles, and the climatic conditions in each season of the year lead to different responses in grapevine phenology, vigor, and yield, as well as in grape quality (Leão et al., 2016; Oliveira et al., 2018).

The grape juice processing industry has grown in this region in recent years based on Vitis labrusca L. and hybrid cultivars, such as 'Isabel Precoce', 'BRS Cora', 'BRS Violeta', and 'BRS Magna' (Leão et al., 2018). The 'Isabel Precoce' cultivar stands out due to its high yield and good quality attributes for juice, with agronomic characteristics similar to those of 'Isabel' grapes, but with a shorter ripening period, which provides a higher number of annual harvests (Ribeiro et al., 2012).

Grapes intended for juice making must have some specific characteristics, such as higher color intensity, high sugar contents, and balanced acidity. Such characteristics affect the quality and typicality of the grape juice and are linked to the peculiarities of each cultivar and to the climatic conditions in the producing region (Leão et al., 2016). Additionally, they are influenced by production factors.

The selection of trellis system and rootstock might affect grapevine development and therefore grapevine yield and grape quality, as the former interferes with the amount of radiation intercepted by the canopy. Solar radiation interception by vineyards has many effects on grape quality, ranging from physical characteristics to phenolic composition. Blancquaert et al. (2019) reported an effect of light quality and quantity on skin total phenol concentration and contents. Conversely, vigor induced by the rootstock affects grapevine physiology and canopy vegetative growth, thus creating a microclimate that affects grapevine development (Silva et al., 2018). Additionally, rootstock has a strong influence on must and its derivative composition. Nevertheless, other factors, such as climate, cultivar, water restrictions, leaf surface/yield ratio, and trellis systems, among others, might impact berry quality either individually or indirectly (Mirás-Avalos and Intrigliolo, 2017).

Therefore, due to the influence of trellis systems and rootstocks on berry quality and composition of grapevines cultivated in tropical regions (Costa et al., 2021), the stability of chemical compounds of commercial interest during the harvest seasons of the same period of the year must be understood. The possibility of lower variations in chemical compound contents, particularly sugars, organic acids, pigments and phenolics, ensures a predictable grape quality across harvests, and thus supports the characterization of typicality for grapes and their derivatives as juices when 'Isabel Precoce' and similar cultivars are grown.

The aim of this study was to characterize the global phenolic composition and antioxidant activity of 'Isabel Precoce' grapes for juice, growing under different trellis systems and rootstocks, in rainy seasons over two years in semi-arid conditions in Brazil.

\section{MATERIALS AND METHODS}

\section{Experimental area}

The experiment was conducted in Petrolina, Pernambuco, Brazil (09 09' S, 40²2' W, 376 m above sea level), in a vineyard planted in December 2015. According to Köppen's classification, the climate in the region is dry semi-arid and low latitude and altitude (BSh), with a mean temperature of 26 ${ }^{\circ} \mathrm{C}$, high light incidence and low annual rainfall that is concentrated from February to April (Alvares et al., 2014). The average annual rainfall in the experimental area and its surroundings was $514.6 \mathrm{~m}$ over a period of 40 years (Embrapa Semiárido, 2018).

Grapevines were trained on three trellis systems (overhead trellis system - OTS; lyre trellis system; vertical shoot positioning - VSP trellis system; all with $3.0 \mathrm{~m} \times 1.0 \mathrm{~m}$ spacing) with rootstocks 'IAC 572' (Vitis caribaea $\times$ '101-14 Mgt') and 'IAC 766' ('106-8 Mgt' $\times$ Vitis caribaea) since planting. Specifically, in VSP, the shoots were arranged to form a vertical downward curtain. Management practices followed the recommendations for Brazilian tropical vitiviniculture, including production pruning, budding induction, topping (Soares and Leão, 2009) and strategies for downy mildew, powdery mildew and rust control.

The grapevines were drip irrigated. The system consisted of four emitters per vine, with flow rates of $2.2 \mathrm{~L} / \mathrm{h}$. Irrigation scheduling was based on pan-A evaporation data collected daily and crop coefficients, varying according to phenological phases. Liquid irrigation depths varied from 9.33 to $21.93 \mathrm{~mm}$ depending on the phenological phase. Nutrients were supplied via irrigation water according to the plant's needs during specific phenological phases and considering the data from the soil and plant analyses. Climatic data during the period are shown in Table I. 
Table I

Monthly meteorological data in the Experimental Field of Bebedouro/Embrapa Semiárido during the harvest seasons ranging from January to May, 2017 (Season 1), and January to May, 2018 (Season 2), when global phenolic composition and antioxidant activity of 'Isabel Precoce' grapes were studied under the influence of trellis systems and rootstocks

\begin{tabular}{|c|c|c|c|c|c|c|c|c|}
\hline \multirow{2}{*}{ Month } & \multicolumn{3}{|c|}{$\mathbf{T}\left({ }^{\circ} \mathrm{C}\right)$} & \multirow{2}{*}{$\begin{array}{l}\text { RH } \\
(\%)\end{array}$} & \multirow{2}{*}{$\begin{array}{c}\text { Rad. } \\
\left(\mathrm{MJ} \mathrm{m}^{-2} \mathrm{dia}^{-1}\right)\end{array}$} & \multirow{2}{*}{$\begin{array}{c}\mathrm{Ws} \\
\left(\mathrm{m} \mathrm{s}^{-1}\right)\end{array}$} & \multirow{2}{*}{$\begin{array}{c}\text { Rainfall } \\
(\mathbf{m m})\end{array}$} & \multirow{2}{*}{$\begin{array}{c}\text { ET0 } \\
\left(\mathrm{mm} \operatorname{dia}^{-1}\right) \\
\end{array}$} \\
\hline & Mean & Max. & Min. & & & & & \\
\hline Jan/17 & 29.3 & 36.0 & 23.2 & 45.1 & 18.2 & 2.4 & 10.2 & 6.3 \\
\hline Apr/17 & 28.0 & 34.2 & 22.6 & 62.0 & 17.4 & 2.4 & 3.2 & 5.4 \\
\hline May/17 & 27.0 & 32.7 & 21.9 & 65.1 & 16.8 & 2.2 & 26.0 & 4.7 \\
\hline Average & 28.4 & 34.8 & 22.9 & 56.8 & 18.4 & 2.2 & 13.9 & 5.5 \\
\hline Feb/18 & 27.3 & 33.7 & 23.1 & 80.0 & 21.5 & 1.2 & 66.1 & 4.9 \\
\hline Mar/18 & 27.5 & 34.1 & 23.0 & 81.2 & 22.9 & 0.9 & 109.4 & 4.8 \\
\hline Apr/18 & 26.2 & 32.3 & 21.6 & 79.3 & 20.6 & 1.1 & 100.5 & 4.3 \\
\hline May/18 & 26.0 & 32.8 & 20.3 & 74.5 & 19.3 & 1.6 & 6.7 & 4.3 \\
\hline Average & 27.1 & 33.6 & 22.3 & 76.0 & 21.6 & 1.3 & 65.1 & 4.9 \\
\hline
\end{tabular}

T Mean = Mean temperature; T Max = Maximum temperature; $\mathrm{T}$ Min = Minimum temperature; $\mathrm{RH}=\mathrm{Air}$ relative humidity; $\mathrm{Rad}=$ Global solar radiation; $\mathrm{Ws}=$ Win speed at a $2.0 \mathrm{~m}$ height; Rainfall $=$ Accumulated rainfall during the month; ET0= Reference evapotranspiration. Source: Agrometeorological Station of Bebedouro, Petrolina, Pernambuco State, Brazil (Embrapa Semiárido, 2018).

\section{Treatments and experimental design}

The treatments corresponded to the three trellis systems, two rootstocks and two harvest seasons: season 1 - from January 23, 2017 (pruning) to May 2, 2017 (harvest); and season 2 - from January 24, 2018 (pruning) to May 21, 2018 (harvest), representing the first and third harvest seasons of the vineyard. During 2017 and 2018, annual rainfall of 123 and $388 \mathrm{~mm}$, respectively, was registered (Embrapa Semiárido, 2018). The average productivity of the vineyard was $14 \mathrm{t} / \mathrm{ha}$ in Season 1 . In Season 2, a variation from 23 to $30 \mathrm{t} / \mathrm{ha}$ was observed.

The experimental design was performed in randomized blocks with split-split plots over time. The plots accounted for the trellis systems, the subplots corresponded to the rootstocks, and the sub-subplots corresponded to the harvest seasons. Four replicates were used with five plants each; from these plants, ten bunches were collected from each experimental plot for analysis of their physical and chemical characteristics, phenolic compounds, and antioxidant activity.

\section{Physical and chemical characteristics}

The grapes were analyzed for their physical and chemical characteristics. The bunch weight (g) was determined using a VI 2400 semi-analytical precision scale (Acculab, model VI 2400, Florida, USA) to calculate the mean value of the set of ten sampled bunches. The berry weight (g) was calculated from the mean weight of fifty berries, sampled from the ten bunches collected and determined using a VI 2400 semi-analytical precision scale (Acculab, model VI 2400, Florida,
USA). The berry resistance to compression (N) was measured using twenty berries, evenly separated from the bunches sampled, and the strength required to cause a $20 \%$ compression in berry volume was measured using a digital Extralab TA.XT.Plus texturometer (Stable Micro Systems, Surrey, UK) with a P/75 pressure plate (Ribeiro et al., 2012). Skin color was measured based on the $\mathrm{L}^{*}$ (lightness), and $\mathrm{a}^{*}$ (+ red, - green) and b* (+ yellow, - blue) CIELAB coordinates, using a digital colorimeter (Konika Minolta, model CR-400, Tokyo, Japan), applied to determine the color of twenty representative berries from the sampled bunches. The titratable acidity ( $\mathrm{g}$ tartaric acid/L) was measured using an automatic titrater (Metrohm, model Titrino plus 848, Herisau, Switzerland). The soluble solids content ( ${ }^{\circ}$ Brix) was determined using a digital refractometer with automatic temperature compensation (ATAGO, model PAL-1, Tokyo, Japan) (AOAC, 2010). The total soluble sugar content $(\mathrm{g} / 100 \mathrm{~g})$ was determined using the anthron reagent (Yemn and Willis, 1954) with a UV-Vis spectrophotometer (Varian, model Cary® 50 Bio, Victoria, Australia).

\section{Phenolic compounds and antioxidant activity}

The total yellow flavonoid and anthocyanin contents in the grape skins $(\mathrm{mg} / 100 \mathrm{~g})$ were extracted using the method proposed by Francis (1982), with an extracting solution containing ethyl alcohol (95\%) and $\mathrm{HCl}(1.5 \mathrm{~N})$ in an 85:15 ratio. The yellow flavonoids were quantified at $374 \mathrm{~nm}$ using a UV-Vis spectrophotometer (Varian, model Cary® 50 Bio, Victoria, Australia), and the total anthocyanins were quantified at $535 \mathrm{~nm}$. Total extractable polyphenols (mg gallic acid/ $100 \mathrm{~g}$ ) were successively extracted in 50\% ethyl alcohol and $70 \%$ acetone solutions from samples comprising ground 
skin and macerated pulp, and their contents were determined using the Folin-Ciocalteu reagent and $20 \%$ sodium carbonate and quantified at $700 \mathrm{~nm}$ in a UV-Vis spectrophotometer (Varian, model Cary® 50 Bio, Victoria, Australia) (Larrauri et al., 1997). The total antioxidant activity was also quantified using the $\mathrm{ABTS}^{\bullet+} \quad[$ acid 2,2'-azino-bis(3-ethylbenzothiazoline-6-sulfonic)] and $\mathrm{DPPH}^{\bullet}$ (2,2-dyphenyl-1-picryl-hydrazyl) free radical capture methods. The procedures described by Miller et al. (1993) and Sánchez-Moreno et al. (1998) were adopted for the $\mathrm{ABTS}^{\bullet+}$ and $\mathrm{DPPH}^{\bullet}$ methods, respectively, using the same UV-Vis spectrophotometer. All determinations were made in duplicate.

\section{Statistical analysis}

The data distribution was assessed using the Shapiro-Wilk test. The data that met a normal distribution were submitted to an analysis of variance, comparing the mean values of the effects of the plots, subplots, and sub-subplots as well as the significant interactions among them using Tukey's test $(p \leq 0.05)$. Only the significant effects derived from the analysis of variance are presented. The Statistical Analysis System program, version 9.2 was used. The data that did not have a normal distribution and did not adjust to any transformation are shown with their mean values and standard deviations. The data were also submitted to a Principal Component Analyses (PCA) to evaluate the response to the treatments according to the variables and to Pearson's correlation using the XLStat program, version 2019.1.

\section{RESULTS AND DISCUSSION}

\section{Physical and chemical characteristics}

The highest bunch weight in season 1 was observed with the trellis systems lyre and VSP, while in season 2 it was observed for the grapevines trained to lyre (Table II). The interaction between the harvest season and rootstock also affected the bunch weight of grapevines grafted onto 'IAC 572', with higher values in season 2 (Table III). Rootstock 'IAC 766' induced a larger bunch weight between seasons, which did not differ from each other. For berry weight, there was no significant effect of the interaction between the harvest season and trellis system. However, in season 1, there was a larger weight of berries harvested from grapevines grafted onto 'IAC 766' than in those harvest one from 'IAC 572' (Table III). Regardless of the season evaluated, there was higher berry weight of grapevines trained with OTS, which did not differ from those trained with VSP (Table IV).

\section{Table II}

Bunch weight, berry resistance to compression and antioxidant activity determined by capturing the free radical $\mathrm{ABTS}^{\bullet+}$ of 'Isabel Precoce' grapes cultivated under three trellis systems, in two harvest seasons in the Brazilian semi-arid region

\begin{tabular}{|c|c|c|c|}
\hline Trellis system & January 23 to May 2, 2017 (Season 1) & January 24 to May 21, 2018 (Season 2) & CV $(\%)$ \\
\hline & \multicolumn{2}{|c|}{ Bunch weight $(\mathrm{g})$} & \\
\hline Vertical shoot positioning & $92.38 \mathrm{aA}$ & $85.71 \mathrm{aB}$ & \\
\hline Lyre & $98.35 \mathrm{bA}$ & $108.07 \mathrm{aA}$ & 7.74 \\
\hline \multirow[t]{2}{*}{ Overhead trellis system } & $80.49 \mathrm{bB}$ & $88.13 \mathrm{aB}$ & \\
\hline & \multicolumn{2}{|c|}{ Berry resistance to compression $(\mathrm{N})$} & \\
\hline Vertical shoot positioning & $7.34 \mathrm{aA}$ & $6.43 \mathrm{bA}$ & \\
\hline Lyre & $7.31 \mathrm{aA}$ & $6.46 \mathrm{bA}$ & 8.06 \\
\hline \multirow[t]{2}{*}{ Overhead trellis system } & $6.91 \mathrm{aA}$ & $7.10 \mathrm{aA}$ & \\
\hline & \multicolumn{2}{|c|}{ Antioxidant activity by $\mathrm{ABTS}^{\bullet+}(\mu \mathrm{M}$ Trolox $/ \mathrm{g})$} & \\
\hline Vertical shoot positioning & $7.45 \mathrm{bB}$ & $7.98 \mathrm{aC}$ & \\
\hline Lyre & $7.00 \mathrm{bC}$ & $10.43 \mathrm{aA}$ & 4.07 \\
\hline Overhead trellis system & $8.46 \mathrm{bA}$ & $8.92 \mathrm{aB}$ & \\
\hline
\end{tabular}


Table III

Bunch weight, berry weight, soluble solids content, titratable acidity and antioxidant activity determined by capturing the $\mathrm{ABTS}^{\bullet+}$ free radical of 'Isabel Precoce' grapes cultivated under two rootstocks, in two harvest seasons in the Brazilian semi-arid region

\begin{tabular}{|c|c|c|c|}
\hline Rootstock & January 23 to May 2, 2017 (Season 1) & January 24 to May 21, 2018 (Season 2) & CV (\%) \\
\hline \multicolumn{4}{|c|}{ Bunch weight $(\mathrm{g})$} \\
\hline 'IAC 572', & $87.06 \mathrm{bB}$ & $95.80 \mathrm{aA}$ & \\
\hline 'IAC 766' & $93.75 \mathrm{aA}$ & $92.14 \mathrm{aA}$ & 7.74 \\
\hline \multicolumn{4}{|c|}{ Berry weight (g) } \\
\hline 'IAC 572' & $2.23 \mathrm{aB}$ & $2.20 \mathrm{aA}$ & \\
\hline 'IAC 766' & $2.46 \mathrm{aA}$ & $2.27 \mathrm{bA}$ & 5.29 \\
\hline \multicolumn{4}{|c|}{ Soluble sugars content (g 100/g) } \\
\hline 'IAC 572' & $20.67 \mathrm{aA}$ & $20.49 \mathrm{aA}$ & \\
\hline 'IAC 766' & $21.03 \mathrm{aA}$ & $19.26 \mathrm{bB}$ & 5.80 \\
\hline \multicolumn{4}{|c|}{ Titratable acidity (g tartaric acid/L) } \\
\hline 'IAC 572' & $6.75 \mathrm{aA}$ & $5.82 \mathrm{bA}$ & \\
\hline 'IAC 766' & $6.18 \mathrm{aB}$ & $5.98 \mathrm{aA}$ & 9.58 \\
\hline \multicolumn{4}{|c|}{ Antioxidant activity by $\mathrm{ABTS}^{\bullet+}(\mu \mathrm{M}$ trolox $/ \mathrm{g})$} \\
\hline 'IAC 572' & $7.38 \mathrm{bB}$ & $9.13 \mathrm{aA}$ & \\
\hline 'IAC 766' & $7.89 \mathrm{bA}$ & $9.09 \mathrm{aA}$ & 4.07 \\
\hline
\end{tabular}

Table IV

Berry weight, soluble solids content and titratable acidity of 'Isabel Precoce' grapes in three trellis systems, in the Brazilian semi-arid region

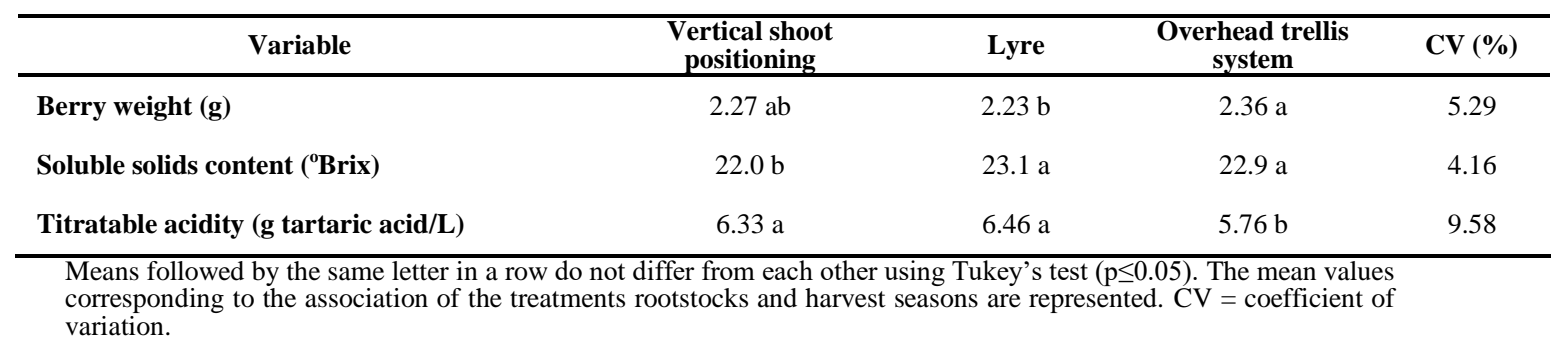

Bunch weight is affected by several factors that were not evaluated in the present study, such as mineral nutrition, foliar area, and water status (Santos et al., 2015); however, some factors might explain the values observed in grapevine samples trained with lyre in season 2. As they have physiological self-regulation mechanisms, grapevines direct their reserves toward vigor or fruiting, depending on the needs (Bem et al., 2015). The type of trellis system might also cause anatomical and physiological changes in the aerial and basal parts (Leão et al., 2016).

OTS is an efficient trellis system in terms of land use in that almost $100 \%$ of the incident light is captured and used by the grapevines, leading to high yields per unit area of land (Creasy and Creasy, 2009), which probably induces larger berry weights. Regarding rootstocks, the most obvious effects on scion behavior include those on scion vigor and on scion water relationships (Sanchez-Rodriguez and Spósito, 2020). Under optimal climate and soil conditions, vigorous rootstocks might lead to excessive vegetative growth, thus negatively affecting productive characteristics (Silva et al., 2018). Therefore, separate from the effect of trellis systems, rootstock 'IAC 766', with lower vigor than
'IAC 572', might enable to reach a higher water and nutrient absorption, thus increasing the berry weight from 'Isabel Precoce' grapevines.

The lowest values of berry resistance to compression were observed in season 2 in berries of grapevines trained with VSP and lyre, 6.43 and $6.46 \mathrm{~N}$, respectively (Table II). It is worth noting that values of berry resistance to compression were similar between seasons in grapevines trained to OTS.

Lower berry resistance to compression indicates softening, which is related to the solubilization of pectins and cell wall degradation. As the cultivar in the present study is intended for juice making, this lower resistance could be result in easier pedicel detachment, which allows for a higher yield during the destemming process that occurs prior to grape maceration (Ribeiro et al., 2012). The solar radiation over $19 \mathrm{MJ} / \mathrm{m}^{2} /$ day and temperatures from 20.3 to $32.8{ }^{\circ} \mathrm{C}$ recorded for the harvest time in season 2 , associated with lyre and VSP canopy architectures, might have provided higher exposure of the berries to radiation. High temperatures and high solar radiation increase the transpiration rate, thus leading to high water tension in the xylem, which prevents it from flowing to the phloem. Therefore, there is 
decreased turgor pressure gradient in the phloem and decreased tissue turgidity, and therefore, reduced berry resistance (Nikinmaa et al., 2012). Leão et al. (2016), evaluating canopy management in 'Syrah' vineyards under tropical conditions, considered that the highest temperatures were recorded near harvest time, along with the practice of restricting irrigation at this time, might have contributed to this response.

In season 1 , the $\mathrm{L}^{*}$ values (representing the color lightness: from 0 - black to 100 - white) of the grapevines grafted onto rootstock 'IAC 766' trained with VSP were higher than those of others, except for those combining lyre or VSP with 'IAC 572' (Table V). In season 2, grapevines grafted onto 'IAC 766 ' trained to VSP had higher lightness than those grafted onto 'IAC 766' trained to lyre. Values of a*, corresponding to the variation from green to red colors, in season 1 varied from 1.00, in grapes grafted onto 'IAC 572' trained to lyre, to 4.10, in grapevines trained to VSP with 'IAC 766' (Table V).
However, it was not possible to identify a treatment that increased red color, which represents positive $\mathrm{a}^{*}$ values. In season 2 , values of $a^{*}$ ranged from 0.45 , in grapevines grafted onto 'IAC 572' trained to lyre, to 1.95 , in plants grafted onto 'IAC 766' trained to OTS. In this season, grapes grafted onto 'IAC 766' trained to OTS were characterized by a redder color than grapes resulting from the combination of lyre and 'IAC 572'. Regarding b*, which represents the variation from blue to yellow colors, more negative values correlate with a stronger violet color. In season $1, \mathrm{~b}^{*}$ values varied from -2.31 , in grapes grafted onto 'IAC 572' trained to lyre, to -0.25 , when plants were grafted on 'IAC 766' trained to OTS (Table V). In season 2, the variation ranged from -0.57 , in grapevines grafted onto 'IAC 572' trained to VSP, to 0.00 , in grapevines grafted onto 'IAC 766' trained to OTS. Only in the first harvest season the OTS treatment combined with 'IAC 766' was differentiated from the others, showing berries with a lighter violet color.

Table V

Mean values and standard deviations of lightness ( $\left.\mathrm{L}^{*}\right), \mathrm{a}^{*}$ and $\mathrm{b}^{*}$ skin color attributes, yellow flavonoids, total anthocyanins, total extractable polyphenol contents and antioxidant activity determined by capturing the free radical $\mathrm{DPPH}^{\bullet}$ of 'Isabel Precoce' grapes according to the trellis systems, rootstocks, and harvest seasons, in the Brazilian semi-arid region

\begin{tabular}{|c|c|c|c|c|}
\hline \multirow{2}{*}{ Trellis system } & \multicolumn{2}{|c|}{ January 23 to May 2, 2017 (Season 1) } & \multicolumn{2}{|c|}{ January 24 to May 21, 2018 (Season 2) } \\
\hline & 'IAC 572' & 'IAC 766' & 'IAC 572' & 'IAC 766' \\
\hline & \multicolumn{4}{|c|}{$\mathrm{L}^{*}$} \\
\hline VSP & $28.80 \pm 0.25$ & $29.35 \pm 0.33$ & $26.66 \pm 0.57$ & $26.76 \pm 0.47$ \\
\hline Lyre & $28.90 \pm 0.85$ & $28.66 \pm 0.27$ & $26.44 \pm 0.44$ & $26.07 \pm 0.21$ \\
\hline OTS & $28.23 \pm 0.45$ & $27.04 \pm 1.12$ & $26.27 \pm 0.50$ & $26.39 \pm 0.81$ \\
\hline \multirow[t]{2}{*}{ CV $(\%)$} & \multicolumn{4}{|c|}{2.36} \\
\hline & \multicolumn{4}{|c|}{$a^{*}$} \\
\hline VSP & $2.24 \pm 0.83$ & $3.14 \pm 0.96$ & $0.75 \pm 0.16$ & $1.24 \pm 0.38$ \\
\hline Lyre & $2.31 \pm 1.31$ & $2.44 \pm 0.61$ & $0.61 \pm 0.16$ & $0.90 \pm 0.19$ \\
\hline OTS & $2.16 \pm 0.80$ & $3.24 \pm 0.46$ & $0.73 \pm 0.15$ & $1.41 \pm 0.54$ \\
\hline \multirow[t]{2}{*}{ CV $(\%)$} & \multicolumn{4}{|c|}{33.76} \\
\hline & \multicolumn{4}{|c|}{$b^{*}$} \\
\hline VSP & $-1.86 \pm 0.41$ & $-1.70 \pm 0.56$ & $-0.42 \pm 0.15$ & $-0.29 \pm 0.15$ \\
\hline Lyre & $-1.78 \pm 0.53$ & $-1.68 \pm 0.15$ & $-0.17 \pm 0.16$ & $-0.10 \pm 0.08$ \\
\hline O'TS & $-1.13 \pm 0.28$ & $-0.45 \pm 0.20$ & $-0.22 \pm 0.22$ & $-0.06 \pm 0.06$ \\
\hline \multirow[t]{2}{*}{ CV $(\%)$} & \multicolumn{4}{|c|}{38.89} \\
\hline & \multicolumn{4}{|c|}{ Yellow flavonoids content (mg/100 g) } \\
\hline VSP & $31.41 \pm 3.87$ & $26.90 \pm 2.18$ & $53.51 \pm 4.05$ & $58.59 \pm 2.04$ \\
\hline Lyre & $30.91 \pm 1.82$ & $37.63 \pm 2.49$ & $45.46 \pm 3.09$ & $60.01 \pm 2.23$ \\
\hline OTS & $35.19 \pm 7.93$ & $30.91 \pm 8.07$ & $56.76 \pm 1.70$ & $35.40 \pm 3.33$ \\
\hline \multirow[t]{2}{*}{ CV $(\%)$} & \multicolumn{4}{|c|}{9.11} \\
\hline & \multicolumn{4}{|c|}{ Total anthocyanins content (mg/100 g) } \\
\hline VSP & $196.73 \pm 17.47$ & $188.35 \pm 28.28$ & \multirow{4}{*}{$\begin{array}{c}150.63 \pm 2.19 \\
297.27 \pm 14.88 \\
225.10 \pm 8.25\end{array}$} & $324.04 \pm 8.51$ \\
\hline Lyre & $219.02 \pm 19.74$ & $206.55 \pm 15.64$ & & $309.77 \pm 15.46$ \\
\hline OTS & $261.57 \pm 28.86$ & $234.53 \pm 27.75$ & & $286.59 \pm 8.28$ \\
\hline CV $(\%)$ & & & & \\
\hline & \multicolumn{4}{|c|}{ Total extractable polyphenols content (mg gallic acid $/ 100 \mathrm{~g}$ ) } \\
\hline VSP & $133.06 \pm 10.45$ & $138.53 \pm 9.00$ & \multirow{4}{*}{$\begin{array}{l}170.83 \pm 2.83 \\
196.52 \pm 4.38 \\
183.81 \pm 3.48\end{array}$} & $189.89 \pm 4.06$ \\
\hline Lyre & $173.58 \pm 13.81$ & $141.45 \pm 20.88$ & & $207.72 \pm 3.03$ \\
\hline OTS & $161.75 \pm 28.24$ & $180.92 \pm 15.55$ & & $180.10 \pm 2.17$ \\
\hline CV $(\%)$ & & & & \\
\hline & \multicolumn{4}{|c|}{ Antioxidant activity by DPPH method (g/g DPPPH } \\
\hline VSP & $9657 \pm 309$ & $9792 \pm 325$ & $10357 \pm 204$ & $8443 \pm 274$ \\
\hline Lyre & $10900 \pm 155$ & $10237 \pm 257$ & $8400 \pm 200$ & $7071 \pm 98$ \\
\hline OTS & $10100 \pm 178$ & $7335 \pm 159$ & $7255 \pm 247$ & $7585 \pm 331$ \\
\hline CV $(\%)$ & & & 2.92 & \\
\hline
\end{tabular}

$\mathrm{L}^{*}$ values in the skin of 'Isabel Precoce' grapes in the present study were lower than those reported by
Ribeiro et al. (2012) in a study conducted in the same region and during the first harvest of the year. Low 
$\mathrm{L}^{*}$ values might derive from a larger amount of epicuticular wax deposited on berries during ripening. It is worth noting that, as this is a cultivar intended both for juice making and fresh consumption, the $\mathrm{L}^{*}$ value is important when the latter is targeted. Skin lightness is not relevant for grapes destined for processing, as the skins become residue in the process after the extraction of their pigments.

Conversely, the intensity of anthocyanic pigments is very important for grape juice and it is related to positive $a^{*}$ values and negative $b^{*}$ values. Therefore, the highest $\mathrm{a}^{*}$ values in season 1 indicate a higher intensity of red, which is associated with anthocyanins. The lowest $\mathrm{a}^{*}$ values were observed in season 2, when the lowest relative air humidity during the ripening phase affected the grape berry growth, as shown in Table I. Under low relative air humidity associated with high temperature, there is a deficit of vapor pressure, resulting in a reduction in transpiration and photosynthesis, which negatively affects the synthesis and accumulation of flavonoids, as well as of anthocyanins (Vogt et al., 1994).

More negative $b^{*}$ values indicate a stronger violet coloration whose intensity depends on the increase in hydroxyl groups in the anthocyanin molecule (Delgado-Vargas et al., 2000). This is a desirable characteristic in grapes intended for juice making once it is recognized that the consumer's preference is for grape juices with a typical violet color. In season 1 , characterized by high temperatures, high solar incidence and low relative air humidity during ripening, the grapes had a stronger violet coloration. In that first season, a lower intensity of violet coloration, indicating a lower number of hydroxyl groups linked to the anthocyanin molecule, was observed in berries harvested from grapevines on rootstock 'IAC 766' trained with OTS. However, factors such as the position of the bunches, determined by the canopy architecture of each trellis system, and the rootstock behavior, all contribute to variations in components that together comprise the pigments that characterize fruit color (Leão et al., 2016). In addition, cultural practices that promote lowering the leaf-to-fruit ratio affect the chromatic characteristics, as observed by Ahumada et al. (2021) in Malbec wines.

The highest soluble solids contents were observed in 'Isabel Precoce' grapes trained with OTS and lyre: 23.1 and $22.9{ }^{\circ}$ Brix, respectively (Table IV). Rootstock 'IAC 572' provided berries of the scion cultivar with the highest soluble solids content (Table VI). Regarding the total soluble sugar contents, the lowest contents were observed in berries harvested from grapevines grafted onto rootstock 'IAC 766' and during the season 2 (Table III). On the other hand, 'IAC 572' promoted equivalent total soluble sugar contents in 'Isabel Precoce' grapes in both harvest seasons.

Table VI

Soluble solids content of 'Isabel Precoce' grapes under influence of two rootstocks, in Brazilian semi-arid region

\begin{tabular}{lccc}
\hline & 'IAC 572' & 'IAC 766' & CV (\%) \\
\hline Soluble solids content $\left({ }^{\circ}\right.$ Brix $)$ & 23.0 a & 22.3 b & 4.16
\end{tabular}

Means followed by the same letter do not differ from each other using Tukey's test $(\mathrm{p}<0.05)$. The mean values corresponding to the association of the treatments trellis systems and harvest seasons are represented. $\mathrm{CV}=$ coefficient of variation

Ahumada et al. (2021) emphasized that a larger canopy expansion induced a higher accumulation of soluble solids in 'Malbec' grapes. In this study, lyre and VSP provided the highest soluble solids contents in grapes, as did rootstock 'IAC 572'. The adoption of this rootstock, which is widely recognized for its high vigor in tropical conditions, resulted in the highest soluble solids contents in berries. This might be explained by the higher uptake of light provided by the systems lyre and OTS systems, validating that the rootstock influences bunch quality even if responses vary according to the climatic conditions, scion cultivar, and trellis system adopted (Ferreira et al., 2019; Costa et al., 2021).

Berries from grapevines grafted onto rootstock 'IAC 572 ' in season 1 were characterized by higher titratable acidity (Table III). 'IAC 766' was observed to contribute to the maintenance of organic acids between harvest seasons, thus producing values of $6.18 \mathrm{~g}$ of tartaric acid/L in season 1 and $5.98 \mathrm{~g}$ of tartaric acid/L in season 2 . This variable was also affected by the trellis systems, with grapevines trained with OTS having the lowest titratable acidity (Table IV).

Organic acid content has been reported to decrease during grape ripening because it is metabolized during the Krebs cycle or converted into sugars by glycogenesis (Famiani et al., 2018). However, the lower titratable acidity in season 2 might also be related to the higher solar radiation recorded during this season, which might have provided increased cell respiration, and consequently, higher degradation of organic acids (Martínez-Lüscher et al., 2016). Ribeiro et al. (2012), assessing 'Isabel 
Precoce' grape quality in consecutive harvest seasons in the Brazilian semi-arid area, observed a titratable acidity of approximately $6 \mathrm{~g}$ of tartaric $\mathrm{acid} / \mathrm{L}$ in the harvest season from the first half of the year, a result similar to that of the present study. Silva et al. (2018) in a tropical climate and dry winter region, observed $8.4 \mathrm{~g}$ of tartaric acid/L in that cultivar. Hence, climatic conditions in the Brazilian semi-arid area are considered to have resulted in higher degradation of organic acids and higher accumulation of sugars in grapes of the 'Isabel Precoce' cultivar, especially due to the higher solar radiation and high temperatures. Additionally, Habran et al. (2016) reported that the rootstock genotype could affect the tartrate and malate contents in compartments of the berry. The response depends on the scion cultivar, revealing the complexity of the rootstocks/scion interactions, and can be expanded when soil composition, climate and particular plant chemical compounds are considered.

\section{Phenolic compounds and antioxidant activity}

Grapevines grafted onto 'IAC 766' trained to lyre provided the highest yellow flavonoid contents in season 1 compared with either grafted onto 'IAC 766 ' trained to VSP or OTS (Table V). In the second season, the highest mean values were observed for grapevines grafted onto 'IAC 766' trained to lyre compared to lyre with 'IAC 572' and OTS with 'IAC $766^{\prime}$. It is expected that trellis systems and rootstocks influence leaf-to-fruit ratios. Consequently, they could modify source-sink ratios, which in turn affect vegetative and reproductive growth and berry composition (Ahumada et al., 2021).

It is important to note the possibility of differentiated responses of a particular compound or some compounds within a chemical group to prevailing plant growing conditions. Martínez-Lüscher et al. (2019) concluded that kaempferol biosynthesis is maintained under high solar radiation, while other yellow flavonoids are degraded. Furthermore, the degradation may be quite sensitive to variations in air temperature during ripening. In addition to the lower solar global radiation, the high temperatures during grape maturation in season 1 compared to season 2 could have caused the lower yellow flavonoid content in the present study (Table V).

Rootstocks differently affected the total anthocyanin contents of the berries of the scion cultivar when combined with OTS under the conditions of the rainy season of 2018 (Table V). In both harvest seasons, adopting VSP combined with 'IAC 572' resulted in the lowest anthocyanin contents in grape skins. This response runs against the interest of improving color in 'Isabel Precoce' grapes in order to better promote juice characteristics, which are more appreciated by consumers. Hence, this combination of trellis systems and rootstock must be avoided.
The combination of trellis systems with rootstocks influences the interception of solar radiation (Ferreira et al., 2019) and causes changes in the chemical composition of the grapes. Within certain limits, solar radiation promotes the biosynthesis of anthocyanins, an effect that might be mediated by the positive regulation between radiation and the gene MYBF1, which induces a response of the gene CHS responsible for the synthesis of phenolics (Martínez-Lüscher et al., 2016). According to the present study, less vigorous rootstocks can result in greater synthesis and accumulation of phenolic compounds in the berries as balanced leaf surfaces are induced by some trellis systems.

Padilha et al. (2017), evaluating the phenolic profile of grapes for juice making, reported higher accumulation of phenolic compounds in a tropical semi-arid region due to high solar radiation incidence. However, different responses observed between trellis systems and rootstocks evaluated during seasons in the same half of the year might be explained mostly by the efficacy of solar radiation absorption by the canopy produced by each trellis system associated with a given rootstock.

Conditions that cause some degree of stress on the plant, whether it is solar radiation, temperature, water, microorganisms or any other factor, might affect the synthesis of phenolic compounds, such as flavonoids (Martínez-Lüscher et al., 2016; Mirás-Avalos and Intrigliolo, 2017; Blancquaert et al., 2019). The highest yellow flavonoid and anthocyanin contents were observed in season 2, characterized by a higher solar radiation, considered a stress factor, during the ripening phase (Tables I and V). However, the response of the anthocyanin contents was related to the adoption of the less vigorous rootstock.

Total extractable polyphenol contents showed higher values in berries harvested from grapevines grafted on 'IAC 766' trained to OTS than those one trained to VSP or grafted onto 'IAC 766' trained to lyre, in the conditions of the season 1 (Table V). In season 2 , it was not possible to distinguish the treatment with the highest potential to accumulate total extractable polyphenols. It is worth highlighting that OTS allowed for lower variations in total extractable polyphenol contents, as well as total anthocyanin contents, according to harvest season. Although the Folin-Ciocalteau method quantifies the phenolic compounds at a wavelength that can receive some interference from sugars, it is largely adopted for fruits. In addition, under the same experimental conditions and scion cultivar, differences among the treatments evaluated are confident and guide important conclusions for the grapevine management.

Total extractable polyphenols are derived from secondary metabolism, and the major factor explaining their accumulation is exposure to 
sunlight, since phenylalanine ammonium-lyase (PAL), an enzyme that catalyzes the reaction in the first stage of the phenolic pathway, is stimulated by light (Wang et al., 2015). Therefore, it is expected that a proper bunch exposure to sunlight stimulates a higher concentration of polyphenols in grapes. However, in cultivation under high global solar radiation and temperatures, a bunch protection of the direct sunlight exposure could maintain the synthesis of phenolic compounds that enhance the quality of grapes and their derivatives. Blancquaert et al. (2019) assumed that shared clusters indicate the strength of the relationship between the phenolic composition, including flavonols and anthocyanins, and sugar accumulation.

According to Costa et al. (2021), grapevine cultivar 'BRS Cora' grafted onto 'IAC 766' trained to lyre accumulates more phenolic compounds as this system promotes a moderate stress when exposing grape bunches to radiation. Vigor might induce an increased canopy density, which influences the grape quality and the accumulation of phenolic compounds (Costa et al., 2021). Thus, it can be inferred that, in general, in plants trained with lyre enabled canopy opening and some bunch protection for adequate capture of incident light. However, according to the present study, this response is only valid for some phenolics groups, such as anthocyanins. Considering the phenolic compounds in general, the responses depend on the rootstock adopted and on the climatic conditions of the harvest season.

The antioxidant activity, determined using the ABTS $^{\bullet+}$ free-radical capture method, was affected by interactions between trellis systems and harvest seasons (Table II), rootstocks and harvest seasons (Table III), and trellis systems and rootstocks (Table VII). The highest antioxidant activities were observed in the rainiest season, with emphasis on grapevines trained on lyre (Table II). Considering the interaction between harvest seasons and rootstocks, the highest antioxidant activity observed using this method was in grapevines grafted onto 'IAC 766' in both harvest seasons (Table III). Regarding the interaction between trellis systems and rootstocks, the lowest antioxidant activity was observed for grapevines grafted on 'IAC 572' trained to VSP (Table VII).

\section{Table VII}

Antioxidant activity determined by capturing the free radical $\mathrm{ABTS}^{\bullet+}$, in $\mu \mathrm{M}$ trolox $\mathrm{g}^{-1}$, of 'Isabel Precoce' grapes cultivated under trellis systems and rootstocks, in Brazilian semi-arid region'

\begin{tabular}{ccc}
\hline Trellis system & \multicolumn{2}{c}{ Rootstock } \\
\cline { 2 - 3 } Lertical shoot positioning $(\boldsymbol{\%})$ \\
Lyre & 'IAC 572' & 'IAC 766' \\
\hline Overhead trellis system & $7.33 \mathrm{bB}$ & $8.09 \mathrm{aA}$ \\
Veans followed by the same lowercase letter in a row or uppercase letter in a column, comparing rootstocks and trellis systems,
\end{tabular}
seasons are represented. $\mathrm{CV}=$ coefficient of variation

Antioxidant activity, determined by the $\mathrm{DPPH}^{\bullet}$ method, varied from $7176 \mathrm{~g} / \mathrm{g}$ DPPH (the highest antioxidant activity), in grapevines grafted onto 'IAC 766' trained with OTS, to $11055 \mathrm{~g} / \mathrm{g} \mathrm{DPPH}$ (the lowest antioxidant activity), with lyre and 'IAC 572', in season 1 (Table V). In season 2, values ranged from $6973 \mathrm{~g} / 100 \mathrm{~g}$, in grapevines trained with lyre and VSP and grafted onto rootstock 'IAC 766', to $10561 \mathrm{~g} / 100 \mathrm{~g}$, in plants grafted onto 'IAC 572' trained with OTS. In season 1, grapevines grafted onto 'IAC 766' trained with OTS provided the highest antioxidant activity, and the lyre-'IAC 572' treatment provided the lowest antioxidant activity. In season 2, the highest antioxidant activity was observed for grapevines from treatments lyre and rootstock 'IAC 766', OTS and 'IAC 572', and OTS and 'IAC 766', and the lowest antioxidant activity was observed for the VSP and 'IAC 572' treatment.

The differentiated response between harvest seasons confirms the results reported by Costa et al. (2021), who studied grapevine cultivar 'BRS Cora' in a tropical climate and correlated environmental conditions with the accumulation of phenolics, which caused differences in the antioxidant activity of the grapes. Similar to total extractable polyphenols, grapevines grafted on 'IAC 766' trained to lyre produced grapes with higher antioxidant activity in season 2, with a higher solar radiation rate, according to the $\mathrm{ABTS}^{\bullet+}$ capture method. This similar response strengthens the hypothesis that antioxidant activity in grapes is directly related to phenolic compounds, which indicates that these compounds provide to benefits for health and explains the importance of consuming grapes and their products (Lorenzo et al., 2017). The highest antioxidant activity determined using the $\mathrm{DPPH}^{\bullet}$ method was equal to that determined by the ABTS $^{\bullet+}$ method. However, the latter showed a better impact of treatments on the final antioxidant activity of 'Isabel Precoce' grapes under semi-arid tropical climatic conditions. 


\section{Principal component analysis}

Components 1 and 2 of PCA explained $71.41 \%$ of the data variation (Figure 1). The total anthocyanin content was the variable with the highest contribution to differentiating the berries from grapevines grafted onto 'IAC 572' trained to OTS in season or productive cycle 2 (OTSR1C2) and from grapevines grafted onto 'IAC 766 ' trained to OTS in season 2 (OTSR2C2). On the other hand, the yellow flavonoid content was the most discriminating variable for lyre associated with 'IAC 572' in season 2 (LR1C2), lyre associated with 'IAC 766' in season 2 (LR2C2), VSP associated with 'IAC 572' in season 2 (VSPRIC2), and VSP associated with 'IAC 766' in season 2 (VSPR2C2). Antioxidant activity, determined by the $\mathrm{DPPH}^{\bullet}$ method, highlighted the treatments lyre with 'IAC 572' in season 1 (LR1C1) and VSP with 'IAC 572' in season 1 (VSPR1C1). Besides, $\mathrm{a}^{*}$ highlighted the treatment comprised of VSP and 'IAC 766' in season 1 (VSPR1C1). Treatments OTSR1C2, OTSR2C2, LR1C2, LR2C2, VSPR1C2, and VSPR2C2 are located in one quadrant, while LR1C1, LR2C1, VSPRIC1, VSPR2C1, OTSR1C1, and OTSR2C1 are distributed in another quadrant, thus emphasizing a marked distinction according to harvest seasons, even though they occur during the same half of the year.

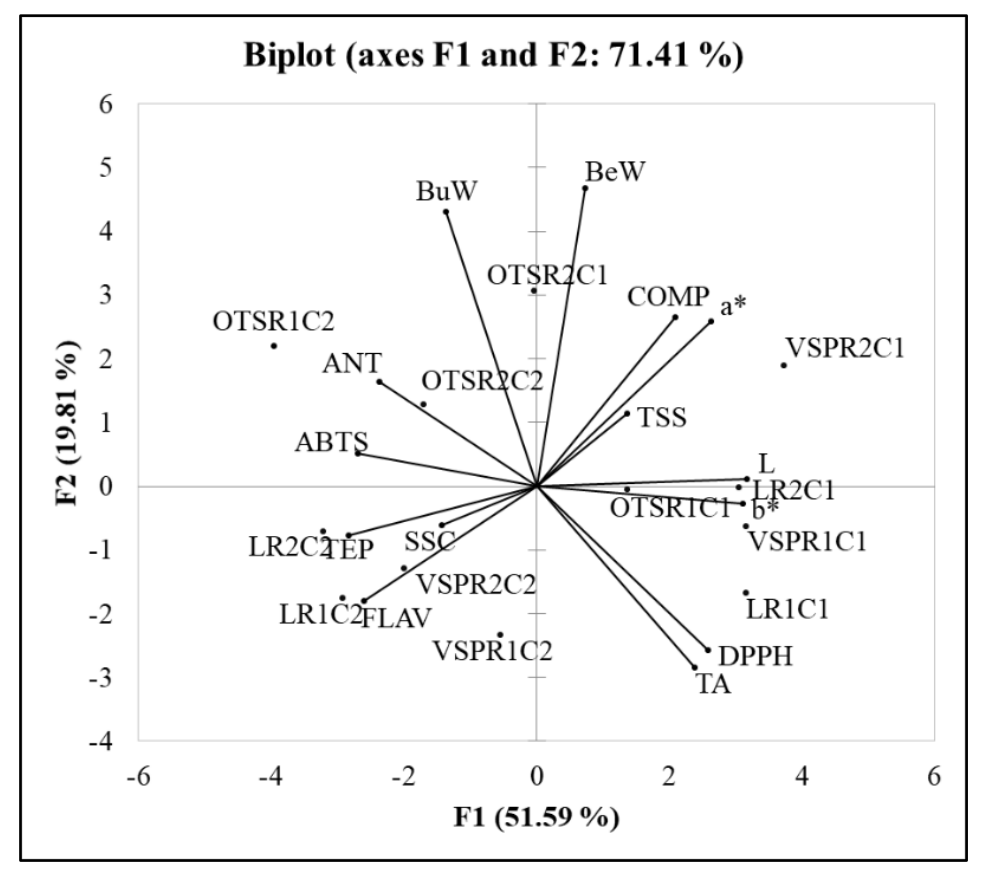

Figure 1. Principal components analysis of the variables which determine quality and antioxidant activity of 'Isabel Precoce' grapes, according to the trellis systems, rootstocks, and production seasons of rainy seasons, in Brazilian semi-arid region. Variables: bunch weight (BuW); berry weight (BeW); soluble solids content (SSC); total soluble sugars (TSS); titratable acidity (TA); berry resistance to compression (COMP); yellow flavonoids in skin (FLAV); total anthocyanins in skin (ANT); total extractable polyphenols (TEP); antioxidant activity by capturing the free radicals $\mathrm{ABTS}^{\bullet+}$ and $\mathrm{DPPH}^{\bullet}$; lightness $\left(\mathrm{L}^{*}\right), \mathrm{a}^{*}$ and $\mathrm{b}^{*}$ skin color attributes. Treatments: OTS= overhead trellis system; $\mathrm{L}=1 \mathrm{yre} ; \mathrm{VSP}=$ vertical shoot positioning; $\mathrm{R} 1=$ rootstock IAC 572; R2= rootstock IAC 766; C1= productive cycle (season) from January to May, 2017; C2= productive cycle (season) from January to May, 2018.

The major variables affected by trellis systems and rootstocks were phenolic compounds, antioxidant activity and color attributes such as a* associated with anthocyanins. Vegetative canopy management practices based on the choice of trellis system and rootstock might affect grapevine development and yield, due to the retention of solar radiation. This response might also provide favorable conditions for phenolic composition and fruit quality (Leão et al., 2018).

As the antioxidant activity of grapes is directly related to phenolic compound content, this activity is also the result of climatic conditions (Costa et al., 2020). Furthermore, trellis systems and rootstocks that promote an adequate leaf surface, allowing protection from the grape bunches from excessive 
solar radiation and heating, are decisive in improving the chemical composition of the berries based on compounds with antioxidant action. These effects are particularly important for vineyards in semi-arid tropical regions.

\section{Correlation analysis}

Positive correlations with coefficients higher than 0.70 were observed between total extractable polyphenols and antioxidant activity according to the ABTS $^{\bullet+}$ method, antioxidant activity determined by this method and $b^{*}, L^{*}$ and $a^{*}$, total extractable polyphenols and $\mathrm{b}^{*}$, and antioxidant activity according to $\mathrm{DPPH}^{\bullet}$ and $\mathrm{L}^{*}$ (Table VIII). Among the variables that represent the methods used to determine antioxidant activity, those that use $\mathrm{DPPH}^{\bullet}$ and $\mathrm{b}^{*}, \mathrm{ABTS}^{\bullet+}$ and $\mathrm{L}^{*}$, in addition to total extractable polyphenols and $\mathrm{L}^{*}$, yellow flavonoid contents and $\mathrm{L}^{*}$, as well as yellow flavonoid contents and $\mathrm{a}^{*}$, had negative correlations higher than 0.70 . Important correlations were also observed between soluble solids contents and total soluble sugars, total extractable polyphenols and yellow flavonoids, anthocyanins and antioxidant activity using the $\mathrm{DPPH}^{\bullet}$ method, and total extractable polyphenols and the same antioxidant activity quantification method. These correlations allow estimating responses among fruit quality variables due to factors related to management or the production environment.

\section{Table VIII}

Pearson's correlation coefficients of the variables bunch weight $(\mathrm{BuW})$; berry weight $(\mathrm{BeW})$; soluble solids content (SSC); total soluble sugars (TSS); titratable acidity (TA); berry resistance to compression (COMP); yellow flavonoids in skin (FLAV); total anthocyanins in skin (ANT); total extractable polyphenols (TEP); antioxidant activity by capturing the free radicals $\mathrm{ABTS}^{\bullet+}$ and $\mathrm{DPPH}^{\bullet}$; lightness $(\mathrm{L}), \mathrm{a}^{*}$ and $\mathrm{b}^{*}$ skin color attributes of 'Isabel Precoce' grapes, according to the trellis systems, rootstocks, and production seasons of rainy seasons, in Brazilian semi-arid region

\begin{tabular}{|c|c|c|c|c|c|c|c|c|c|c|c|c|c|}
\hline Variable & $\mathrm{BeW}$ & SSC & TSS & TA & COMP & FLAV & ANT & TEP & ABTS & DPPH & $\mathbf{L}^{*}$ & $a^{*}$ & $\mathbf{b}^{*}$ \\
\hline BuW & 0.388 & 0.037 & 0.029 & -0.418 & 0.140 & -0.009 & 0.527 & 0.042 & 0.294 & -0.531 & -0.261 & 0.049 & 0.341 \\
\hline BeW & & -0.341 & 0.018 & -0.042 & 0.235 & -0.354 & -0.030 & -0.257 & -0.059 & -0.212 & 0.224 & 0.503 & -0.042 \\
\hline SSC & & & 0.678 & -0.309 & -0.132 & 0.278 & 0.379 & 0.393 & 0.338 & -0.120 & -0.315 & -0.381 & 0.218 \\
\hline TSS & & & & -0.120 & 0.066 & -0.137 & -0.001 & -0.066 & -0.080 & 0.233 & 0.182 & 0.168 & -0.256 \\
\hline TA & & & & & 0.081 & -0.393 & -0.520 & -0.371 & -0.337 & 0.518 & 0.546 & 0.312 & -0.468 \\
\hline COMP & & & & & & -0.476 & -0.183 & -0.366 & -0.301 & 0.173 & 0.498 & 0.529 & -0.361 \\
\hline FLAV & & & & & & & 0.546 & 0.631 & 0.498 & -0.417 & -0.708 & -0.730 & 0.613 \\
\hline ANT & & & & & & & & 0.500 & 0.530 & -0.653 & -0.540 & -0.488 & 0.486 \\
\hline TEP & & & & & & & & & 0.748 & -0.610 & -0.775 & -0.564 & 0.717 \\
\hline ABTS & & & & & & & & & & -0.753 & -0.703 & -0.463 & 0.737 \\
\hline DPPH & & & & & & & & & & & 0.709 & 0.313 & -0.723 \\
\hline $\mathbf{L}^{*}$ & & & & & & & & & & & & 0.720 & -0.829 \\
\hline $\mathbf{a}^{*}$ & 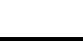 & 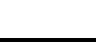 & & & & & & & & & & & -0.447 \\
\hline
\end{tabular}

The same chemical nature explains the high correlation between total extractable polyphenols and yellow flavonoids quantified in the skin. Flavonoids are comprised of two phenolic rings and one heterocyclic ring and are divided into many subgroups according to the oxidation status of the latter (Zhang and Tsao, 2016). Additionally, the high correlation between total extractable polyphenols and antioxidant activity according to the ABTS ${ }^{\bullet+}$ and $\mathrm{DPPH}^{\bullet}$ methods, as well as between total anthocyanin contents and antioxidant activity according to $\mathrm{DPPH}^{\bullet}$, observed in grapes growing under tropical semi-arid conditions and management, corroborates the assumption that the antioxidant potential is directly related to the compounds of secondary metabolism (Lorenzo et al., 2017).

The correlation between skin color attributes $\left(\mathrm{L}^{*}, \mathrm{a}^{*}\right.$, and $\left.b^{*}\right)$ and the variables that measure phenolic compounds and antioxidant activity might be explained by the fact that the major pigments responsible for the color of red grapes anthocyanins - result from secondary metabolism (Leão and Lima, 2018). The fact that antioxidant activity values observed using the $\operatorname{ABTS}^{\bullet+}$ and $\mathrm{DPPH}^{\bullet}$ free radical capture methods are correlated to each other indicates that consistent conclusions regarding grapes might be reached using both methods (Lorenzo et al., 2017).

\section{CONCLUSIONS}

The predominant environmental conditions during harvest seasons affected the quality and antioxidant activity of 'Isabel Precoce' grapes cultivated under a tropical climate, and the responses were differentiated according to the trellis system and rootstock. Rootstock 'IAC 766' provided equivalent values of bunch weight and titratable acidity between harvest seasons, while 'IAC 572' produced an 
equivalence between total soluble sugar contents. However, when combined with vertical shoot positioning, this rootstock did not allow for the anthocyanin content to be comparable to the other treatments, which represents a setback for the end product. Values of berry resistance to compression, total extractable polyphenol and anthocyanin contents did not differentiate between seasons in plants trained with an overhead trellis, regardless of the rootstock. Regarding the yellow flavonoid contents, only when associated with 'IAC 766' did an overhead trellis result in equivalent values between seasons. Lyre in season 2, characterized by higher solar radiation, provided higher antioxidant activity according to the $\mathrm{ABTS}^{\bullet+}$ free radical capture method. On the other hand, an overhead trellis associated with rootstock 'IAC 766' provided similar responses between harvest seasons as well as high antioxidant activity according to the $\mathrm{DPPH}^{\bullet}$ method. Therefore, the overhead trellis system, regardless of the rootstock used, proved to be more efficient in providing stability to the phenolic composition and antioxidant activity of 'Isabel Precoce' grapes during rainy seasons, thus ensuring some predictability in the quality of the grapes and their products in successive harvests.

\section{ACKNOWLEDGEMENTS}

The authors would like to thank CAPES for the grant of a postgraduate scholarship to the lead author. Our thanks also go to Embrapa, for the infrastructure and financial support (Project no. 02.13.06.002.00.00), and Rodrigo Silva Liborio and agriculture workers of Bebedouro Experimental Field.

\section{REFERENCES}

Ahumada G.E., Catania A., Fanzone M.L., Belmonte M.J., Giordanoc C.V., González C.V., 2021. Effect of leaf-to-fruit ratios on phenolic and sensory profiles of Malbec wines from single high-wire-trellised vineyards. J Sci Food Agric., 101, 1467-1478.

Alvares C.A., Stape J.L., Sentelhas P.C., Gonçalves J.L. de M., Sparovek G., 2014. Köppen's climate classification map for Brazil. Meteorol. Z., 22, 711-728.

Association of Official Agricultural Chemists (AOAC). 2010. Official methods of analysis of the Association of the Agricultural Chemistis. 18ed. AOAC, Gaithersburg, MD, USA.

Bem B.P. de, Bogo A., Everhart S., Casa R.T., Gonçalves M.J., Filho J.L.M., Cunha I.C. da., 2015. Effect of Y-trellis and vertical shoot positioning training systems on downy mildew and botrytis bunch rot of grape in highlands of southern Brazil. Sci. Hortic., 185, 162-166.

Blancquaert E.H., Oberholster, A., Ricardo-da-Silva J.M., Deloire, A.J., 2019. Grape flavonoid evolution and composition under altered light and temperature conditions in Cabernet Sauvignon (Vitis vinifera L.). Front. Plant Sci., 10, 1062.

Costa R.R., Ferreira T.O., Lima M.A.C., 2021. Training systems, rootstocks and climatic conditions influence quality and antioxidant activity of 'BRS Cora' grape. Acta Sci. Agron., 43, e49054.

Costa R.R., Rodrigues A.A.M., Vasconcelos V.A.F., Costa J.P.D., Lima M.A.C., 2020. Trellis systems, rootstocks and season influence on the phenolic composition of 'Chenin Blanc' grape. Sci. Agric., 77, e20180207.

Creasy G.L., Creasy L.L., 2009. Grapes. Crop production Science in Horticulture. London, UK, Europe.

Delgado-Vargas F., Jiménez A.R., Parede-López O., 2000. Natural pigments: carotenoids, anthocyanins, and betalains characteristics, biosynthesis, processing, and stability. Crit. Rev. Food Sci. Nutr., 40, 173-289.

Embrapa Semiárido. 2018. Médias Anuais da Estação Agrometeorológica de Bebedouro, Petrolina-PE. Embrapa Semiárido.

Famiani F., Paoletti A., Proietti P., Battistelli A., Moscatello S., Cruz-Castillo J.G., Walker R.P., 2018. The occurrence of phosphoenolpyruvate carboxykinase (PEPCK) in the pericarp of different grapevine genotypes and in grape leaves and developing seeds. J. Hortic. Sci. Biotechnol., 93, 456-465.

Ferreira T.O., Costa R.R., Felix D.T., Andrade Neto E.R., Cruz M.M., Lima M.A.C., 2019. Quality and antioxidant potential of 'BRS Magna' grapes harvested in the first half of the year under different training systems and rootstocks in a tropical region. Ciênc. Agrotec., 43, e029518.

Francis F.J., 1982. Analysis of anthocyanins. In: Anthocyanins as food colors. 181-207. Markakis, P. (ed.), New York, NY, USA.

Habran A., Commisso M., Helwi P., Hilbert G., Negri S., Ollat N., Gomès E., van Leeuwen C., Guzzo F., Delrot S., 2016. Roostocks/scion/nitrogen interactions affect secondary metabolism in the grape berry. Front. Plant Sci., 7:1134.

Larrauri J.A., Rupérez P., Saura-Calixto F., 1997. Effect of drying temperature on the stability of polyphenols and antioxidant activity of red grape pomace peels. J. Agric. Food Chem., 45, 1390-1393.

Leão P.C. de S., Lima M.A.C., 2018. Canopy management of table grapes cultivar in tropical conditions. J. Agr. Sci. Tech., 8, 228-233.

Leão P.C. de S., Nunes B.T.G., Lima M.A.C., 2016. Canopy management effects on 'Syrah' grapevines under tropical semi-arid conditions. Sci. Agric., 73, 209-216.

Leão P.C. de S., Rego J.I. de S., Nascimento J.H.B., Souza E.M. de C., 2018. Yield and physicochemical characteristics of 'BRS Magna' and 'Isabel Precoce' grapes influenced by pruning in the São Francisco river valley. Cienc. Rural, 48 , e20170463.

Lorenzo C., Badea M., Colombo F., Orgiu F., Frigerio G., Pastor R.F., Restani P., 2017. Antioxidant 1 of wine assessed by different in vitro methods. BIO Web Conf., 9, 04008.

Martínez-Lüscher J., Brillante L., Kurtural S.K., 2019. Flavonol profile is a reliable indicator to assess canopy architecture and the exposure of red wine grapes to solar radiation. Front. Plant Sci., 10, 10.

Martínez-Lüscher J., Sánchez-Días M., Delrot S., Aguirreolea J., Pascual I., Gomès E., 2016. Ultraviolet-B alleviates the uncoupling effect of elevated $\mathrm{CO}_{2}$ and increased temperature on grape berry (Vitis vinifera $\mathrm{cv}$. Tempranillo) anthocyanin and sugar accumulation. Aust. J. Grape Wine Res., 22, 87-95.

Miller N.J., Diplock A.T., Rice-Evans C., Davies M.J., Gopinathan V., Milner A., 1993. A novel method for measuring antioxidant capacity and its application to monitoring the antioxidant status in premature neonates. Clin. Sci., 84, 407-412. 
Mirás-Avalos J.M., Intrigliolo D.S., 2017. Grape composition under abiotic constrains: water stress and salinity. Front. Plant Sci., 8, 851

Nikinmaa E., Hölttä T., Hari P., Kolari P., Mäkelä A., Sevanto S., Vesala T., 2012. Assimilate transport in phloem sets conditions for leaf gas exchange. Plant Cell Environ., 36, 655-669.

Oliveira J.B., Faria D.L., Duarte D.F.; Egipto R.; Luareano O., Castro R. de, Pereira G.E., Ricardo-da-Silva J.M. 2018. Effect of the harvest season on phenolic composition and oenological parameters of grapes and wines cv. 'Touriga Nacional' (Vitis vinifera L.) produced under tropical semi-arid climate, in the state of Pernambuco, Brazil. Ciência Téc. Vitiv., 33, 145-166.

Padilha C.V.S., Miskinis G.A., Souza M.E.A.O., Pereira G.E., Oliveira D., Bordignon-Luiz M.T., Lima M.S., 2017. Rapid determination of flavonoids and phenolic acids in grape juices and wines by RP-HPLC/DAD: Method validation and characterization of commercial products of the new Brazilian varieties of grape. Food Chem., 228, 106-115.

Ribeiro T.P., Lima M.A.C., Alves, R.E., 2012. Maturação e qualidade de uvas para suco em condições tropicais, nos primeiros ciclos de produção. Pesq. Agropec. Bras., 47, 1057-1065.

Sánchez-Moreno C., Larrauri J.A., Saura-Calixto F., 1998. A procedure to measure the antiradical efficiency of polyphenols. J. Sci. Food Agric., 76, 270-276.

Sanchez-Rodriguez L.A., Spósito M.B., 2020. Influence of the trellis/training system on the physiology and production of Vitis labrusca cv. Niagara Rosada in Brazil. Sci. Hortic., $261,109043$.

Santos A.O., Pereira A.E., Moreira C.A., 2015. Qualidade físico-química da uva e perfil sensorial vínico para diferentes cultivares de videira submetidas à poda mecanizada. Rev. Bras. Frutic., 37, 432-441.

Silva M.J.R. da, Paiva A.P.M., Pimentel Junior A., Sánchez C.A.P.C., Callili D., Moura M.F., Leonel S., Tecchio M.A. 2018. Yield performance of new juice grape varieties grafted onto different rootstocks under tropical conditions. Sci. Hortic., 241, 194-200.

Soares J.M., Leão P.C.S., 2009. A vitivinicultura no Semiárido brasileiro. Petrolina, PE, Brasil.

Vogt T., Pollak P., Taryln N., Taylor L.P., 1994. Pollinationor wound-induced kaempferol accumulation in petunia stigmas enhances seed production. Plant Cell, 6, 11-23.

Wang J., Ma L., Xi H., Wang L., Li S., 2015. Resveratrol synthesis under natural conditions and after UV-C irradiation in berry skin is associated with berry development stages in 'Beihong' (V. vinifera x V. amurensis). Food Chem., 168, 430-438.

Yemn E.W., Willis A.J., 1954. The estimation of carbohydrate in plant extracts by anthrone. Biochem. J., 57, 504-514.

Zhang H., Tsao R., 2016. Dietary polyphenols, oxidative stress, antioxidant, and anti-inflammatory effects. Curr. Opin. Food Sci., 8, 33-42. 